\title{
Representações cinematográficas do jornalismo investigativo em Todos os homens do presidente (1976) e Spotlight (2015) ${ }^{1}$
}

\section{Cinematographic representations of investigative journalism in All The president's men (1976) and Spotlight (2015)}

\section{Fernanda Lima Lopes}

Doutora emestreem Comunicaçãoe Cultura(UFRJ), realiza estágio pós-doutoral naEscola deComunicação da UFRJ.Tem experiência como docentena pós-graduação(ECO/UFRJ;UVA-RJ;Unesa-RJ) ena graduaçãoem Comunicação(UnilesteMG;ECO/UFRJ,Unesa-RJ). $<$ ferdynanda@yahoo.com>

\section{Maurício da Silva Duarte}

Doutor em Comunicação e Cultura pela Universidade Federal do Rio de Janeiro. Concluiu estágio pós-doutoral em Comunicação na Escola de Comunicação da Universidade Federal do Rio de Janeiro (ECO/UFRJ). Professor titular do curso de Comunicação Social da Universidade Salgado de Oliveira.

<dmausage@gmail.com>

\section{Itala Maduell Vieira}

Professora de Jornalismo no Departamento de Comunicação Social da PUC-Rio, é doutoranda do Programa de Pós-Graduação em Comunicação da Universidade do Estado do Rio de Janeiro.

<italamad@gmail.com>

\section{RESUMO}

O artigo avalia a construção dos sentidos mobilizados em relação à figura do jornalista investigativo em produções cinematográficas, com o propósito de entender estas representações e de que modos interagem com os processos de construção da identidade jornalística. São analisadas duas produções hollywoodianas, baseadas em casos reais: Todos os homens do presidente, de 1976; e Spotlight, de 2015. Os filmes mobilizam estereótipos duradouros (credibilidade, neutralidade, heroísmo) sobre os jornalistas investigativos e a um dado reconhecimento de seu poder no espaço social. Além disso, essas narrativas apresentam-se, elas mesmas, como versões "neutras" e verídicas sobre os fatos que abordam, apagando os processos de seleção e edição - comuns ao jornalismo e ao cinema - e, no caso do segundo, o próprio contexto do jornalismo no século XXI.O referencial teórico-metodológico se apoia na análise de discurso textualmente orientada (Fairclough, 2001) e na semiologia dos discursos sociais (Pinto, 2002).

\section{ABSTRACT}

The article evaluates within cinematographic productions the construction of the senses related to the investigative journalist's images. The aim is to understand these representations and in what ways they interact with the processes of journalistic identity construction. Two Hollywood movies, based on real cases, are analyzed: All the president's men (1976) and Spotlight (2015). Both mobilize lasting stereotypes (credibility, neutrality, heroism) about investigative journalists and a given recognition of their power in the social space. Moreover, these narratives present themselves as "neutral" and truthful versions of the facts that they address, blurring the processes of selection and editing - common to journalism and cinema- and, in the case of the 2015's movie, it also erases the context of journalism in the 21st century. The theoreticalmethodological framework is based on the analysis of textually oriented discourse (Fairclough, 2001) and on the semiology of social discourses (Pinto, 2002).

Keywords: Journalism. Professional identity. Cinema. 


\section{Introdução}

Ao abordar práticas de jornalismo investigativo na imprensa americana, os filmes hollywoodianos Todos os homens do presidente (EUA, 1976) e Spotlight - Segredos revelados (EUA, 2015) constroem representações do profissional e das atividades por ele exercidas, contribuindo para a produção de sentidos do jornalismo de maneira mais ampla. Esses filmes corroboram e exemplificam a tradição de proximidade entre cinema e jornalismo já apontada por estudos acadêmicos (Santos, 2009; Oliveira, 2005; Berger, 2002). O jornalismo e o cinema têm uma relação próxima desde que os primeiros filmes começaram a ser feitos. Como enfatiza Marcelle Santos (2009), essa proximidade se deu tanto na produção de filmes ficcionais com a temática em torno do jornalismo e de jornalistas como no que diz respeito à produção de documentários e veiculação de notícias nos chamados cinejornais. Em obra sobre jornalismo e cinema, Christa Berger (2002) faz um levantamento de 785 filmes cujo tema central tenha sido o universo jornalístico, e aponta a primazia dos Estados Unidos, com 536 obras nesse tipo de abordagem cinematográfica.

Todos os homens do presidente reconta, sob o viés do protagonismo dos repórteres Bob Woodward e Carl Bernstein, do Washington Post, o chamado Escândalo Watergate, que levou à renúncia do então presidente dos Estados Unidos, Richard Nixon, em 1974, após dois anos de investigações. Spotlight traz como tema a cobertura realizada entre 2001 e 2002 pela equipe especial de reportagem (chamada Spotlight) do jornal The Boston Globe, acerca de denúncias de pedofilia envolvendo a Igreja Católica em Massachusetts. O então arcebispo de Boston, Bernard Shaw, acabou renunciando em dezembro de 2002.Dois contextos bastante distintos, que nas produções cinematográficas se aproximam por meio deestratégias discursivas muito similares, como discutiremos a seguir.

As narrativas de ambos os filmes constroem a imagem de uma imprensa heroica, paladina da verdade e da imparcialidade. O exercício de reflexão é perceber como essas narrativas heroicas, produzidas em seus respectivos períodos históricos e com suas particulares referências temáticas, constroem representações do jornalista, e de que modo tais representações reverberam os contextos em que tais discursos são produzidos ao mesmo tempo em que ajudam a constituir esse contexto.

Esteartigo também busca discutir de que maneira os filmes eventualmente silenciam sobre temas fundamentais nos estudos teóricos sobre o jornalismo. Como se verá, boa parte das representações cinematográficas analisadas promove, particularmente, um silêncio sobre o caráter negociado da seleção e produção de notícias e, consequentemente, sobre os conflitos de poder 
presentes no exercício da profissão. A estrutura de um artigo não permite uma análise exaustiva dos filmes. De qualquer forma, no esforço comparativo, procuraremos jogar luz sobre a relação desses discursos contextualizados com as representações por eles engendradas.

Os filmes estão aqui sendo compreendidos como textos. Como explica Milton José Pinto, os textos não se referem apenas a palavras escritas, mas também a "[...] formas empíricas do uso da linguagem verbal, oral ou escrita, e/ ou outros sistemas semióticos no interior de práticas sociais contextualizadas histórica e socialmente [...]" (Pinto, 2002, p.11). O processo de construção de qualquer trabalho estético, por exemplo, adaptações de casos reais para o cinema, envolve a seleção de cenas e acontecimentos considerados mais relevantes ou convenientes para os realizadores. Ou seja, as próprias características estéticas dos filmes ocorrem dentro de um contexto, não sendo ideologicamente neutras.

Sob essa perspectiva, valorizamos neste trabalho o eixo teórico baseado numa tradição de análise de textos, levando em conta as mudanças nos focos conceituais de significado (que pressupõe uma base fixa, fechada no sistema linguístico) para sentido (que não se separa do contexto e é atravessado por lutas sociais), e que estão associadas às obras de Bakhtin, Foucault e Pêcheux, por exemplo. Desde Bakthin (1992), nas décadas de 1930 e 40, essa linha teórica rejeita o corolário de que o texto (literário ou estético) é um produto acabado, cujo exame deva se limitar a uma análise imanente. Reforça-se, portanto, que a produção ocorre dentro de um dado ambiente ideológico, em que a autoridade estética do autor é relativizada. A partir de conceitos como polifonia e dialogismo (Bakhtin, 1986) entendem-se as obras como representações discursivas híbridas, constituídas pela vocalização de discursos sociais distintos e, por vezes, antagônicos, que comumente escapam ao controle do próprio autor.

Ao investigar as representações sobre jornalismo investigativo nos filmes escolhidos para o corpus deste trabalho, é preciso encontrar e explicitar marcas textuais e extratextuais que remetam às imagens e possíveis estereótipos de jornalistas, bem como traços das relações sociais que as práticas discursivas ensejam na construção das identidades sociais. O conceito de intertextualidade é chave para o referencial teórico-metodológico adotado neste artigo, que se apoia na análise de discurso textualmente orientada de Norman Fairclough (2001) e na semiologia dos discursos sociais de Milton José Pinto (2002). Como resumem Charaudeau e Maingueneau (2006), o termo intertextualidade designa ao mesmo tempo uma propriedade constitutiva de qualquer texto e o conjunto das relações explícitas ou implícitas que um texto mantém com outros textos. 
Seguimos aqui a tendência iniciada por Maingueneau de usar intertexto para relações com textos-fonte precisos, como as citações ou paródias².

Oswald Ducrot (1984) e Kerbrat-Orecchioni (1986) distinguem dois tipos de implícitos em especial, um excluindo e outro incluindo o contexto (Pinto e Duarte, 2005). As "pressuposições" podem ser recuperadas automaticamente sem mobilizar recursos contextuais, a partir do próprio enunciado. Isso se dá por meio de inferências, cujo "gatilho" desencadeador são as marcas formais encontradas na superfície dos textos - abordaremos algumas dessas pressuposições na análise de cenas selecionadas dos filmes. Por outro lado, os subentendidos exigem a mobilização de elementos contextuais, sem os quais não podem ser recuperados pelo receptor, como insinuações, alusões e outros modos indiretos de falar. Embora sejam atribuídos ao receptor-intérprete pelo emissor, nem sempre o receptor possui os recursos necessários para recuperar os elementos contextuais.

Abordaremos ainda alguns conceitos teóricos dojornalismo para explicitar o caráter conflitivo da produção da notícia e mesmo das representações sociais sobre esse processo. As representações da realidade social sempre fornecem uma narrativa parcial da realidade, que, porém, “[...] é adequada a alguma proposta [...]" (Becker, 1994, p. 136). Notícias e filmes sobre elas são marcadas por rotinas produtivas, limitações organizacionais e expectativas de reconhecimento do público que influenciam e condicionam o produto final. Portanto, assim como pretendemos mostrar sobre a notícia, qualquer representação da realidade tem um caráter intencional e negociado.

Paralelismos discursivos nos filmes e representações do dinamismo, heroísmo e comprometimento do jornalista investigativo

Antes de partir para a análise pormenorizada das obras, é interessante pontuar que elas estão ambientadas em instituições do jornalismo impresso, mas em termos temporais localizam-se em diferentes cenários comunicacionais. Foram concebidas em épocas radicalmente distintas, sobretudo no que diz respeito ao contexto das dinâmicas de comunicação, incluindo aí as diferentes configurações sociais e os vínculos sociais em relação à cultura e às tecnologias midiáticas. Mesmo assim, não se diferenciam muito no que tange às representações sobre a prática cotidiana dentro da redação de um jornal impresso. Todos os homens do presidente, dos anos 1970, é de um momento em que a mídia impressa, mais antiga e consolidada que o rádio e a TV, era o

2 Para a heterogeneidade constitutiva de todos os textos, isto é, a característica de serem formados de fragmentos de outros textos, vamos preferir o termo interdiscursividade, ainda seguindo Maingueneau. 
principal meio para o exercício jornalístico. E, distinguindo-se ainda do caráter mais sucinto e imediatista dos audiovisuais, apresentava-se como espaço privilegiado para os jornalistas investigativos.

Já porvolta dos primeiros anos do milênio, a rede mundial decomputadores era realidade nas empresas de comunicação e na vida de pessoas comuns, com acesso a recursos digitais como e-mails, sites, salas de bate-papo e portais de informação. Se em 2001, época em que se passa o enredo de Spotlight, ainda não se experimentava o que Tim O'Reilly (2005) vai chamar de web 2.0 - etapa de maior imersão do usuário na produção de conteúdo on-line e na emergência das redes sociais -, já era possível identificar uma série de transformações no jornalismo estimuladas pelas dinâmicas de comunicação na internet. Essas mudanças se verificam na realização do trabalho jornalístico, desde a dimensão de apuração das notícias, levantamento de dados, contato com as fontes, até o modo de distribuição informativa pelas redes. Tais dinâmicas, em avançado curso nas empresas midiáticas de grande porte, já chamavam a atenção da comunidade acadêmica, como se pode observar, por exemplo, em Journalism and new media, obra de 2001 em que o professor John Pavlik, da Universidade de Columbia, atenta aos "impactos da nova mídia" em diferentes dimensões do jornalismo.

No entanto, em Spotlight, as imagens da redação do Boston Globe remetem a configurações dos anos 1970 ou 1980, e até a fotografia do filme parece remeter à de Todos os homens do presidente. Quase não se percebe a interferência da internet no universo jornalístico, sobretudo nas imagens da infraestrutura da redação. Aliás, se não fosse por terminais de computador em vez de máquinas de escrever sobre as estações de trabalho, as redações mostradas em ambos os filmes seriam praticamente idênticas: iluminação branca no teto de cor clara, mesas distribuídas sob a forma de estações de trabalho com seus ramais de telefone fixo, ritmo frenético de jornalistas digitando seus textos ou transitando com pressa, colegas de trabalho que vão às mesas uns dos outros, chefes que recebem os jornalistas em suas salas, mantendo a pose de autoridade.

No caso de Todos os homens do presidente, o produtor e ator norteamericano Robert Redford (que interpretou Bob Woodward) empreendeu esforços para buscar a verossimilhança com a redação real do Washington Post, com a consultoria de seus jornalistas. Como não foi possível filmar na própria, foi construída uma réplica fiel: "A equipe de produção listou cada item da redação", conta Redford no documentário All the president's men - Telling the true about lies (Redford, 2006). "Pegaram lixo dos cestos da redação do Post e mandaram para a Califórnia, para dar autenticidade. Juntaram dois estúdios da Warner, quebrando a parede, para dar a exata profundidade", acrescenta Dustin 
Hoffman, que fez dois meses de laboratório no Post para interpretar o repórter Carl Bernstein (Hoffman, 2006).

Já em Spotlight, há um intertexto presente nos enquadramentos de cenas que retratam o cotidiano da redação do Boston Globe e dos jornalistas da equipe especial, inspiradas não na redação real, mas em cenas da clássica redação do Washington Post de Todos os homens do presidente. A referência explícita oferta sentido de continuidade entre as redações. Em especial, o subentendido é de que permanecem semelhantes principalmente em relação às pressões políticas ainda hoje enfrentadas pelos jornalistas.

Além das cenas na redação, a lida cotidiana desses profissionais é apresentada pelos dois filmes por tomadas na "rua". As locações exteriores podem ser um tribunal, bibliotecas públicas, lugares onde os repórteres se encontram com suas fontes: a casa delas, um café, pub, lanchonete, ou um local discreto e reservado quando o informante não quer ser visto com o jornalista. As cenas e cenários aproximam-se para mostrar uma profissão que tem uma rotina dinâmica e vivamente integrada aos espaços e às pessoas da cidade, incluindo os poderosos. Vale destacar, em particular, a reiteração da sequência de cenas da "peregrinação" dos repórteres, indo de casa em casa, tocando campainhas e encontrando várias portas fechadas na busca por fontes para as matérias. No filme de 1976, os repórteres Woodward e Bernstein vão atrás das pessoas que trabalharam como funcionários no comitê de reeleição de Nixon e, no de 2015, os jornalistas Sasha Pfeifer e Matt Carol procuram vítimas e padres acusados de pedofilia. O paralelismo estético e narrativo é bastante acentuado, ambos mostrando jornalistas que trabalham de modo ativo, dinâmico, movimentandose pela cidade, realizando sua investigação a todo tempo e em todo lugar.

Oliveira (2005) observa que o filme sobre Watergate é referência para a representação do jornalista como cão de guarda (watch dog journalism) das instituições democráticas e do jornalismo como contra poder. Merece menção a estratégia de valorizar a penumbra e do jogo do grande para o pequeno, e do pequeno para o grande, como nas cenas da biblioteca, e do carro dos repórteres na rua, abrindo para um grande plano da cidade onde buscavam informação como agulha num palheiro. Há um jogo de aproximações e distâncias, ora detalhe, ora grandiosidade. Do close dos dedos folheando os cartões da biblioteca, a câmera vai se distanciando até tornar os personagens dois pequenos detalhes. $O$ jogo de cena sugere estarem próximos demais, ou distantes demais, para enxergar o que buscam. Nomaking-of da época, o diretor Allan J. Pakula (1928-1998) justifica a escolha recorrendo à imagem do jornalista como um cão de guarda fiel e valente, que enfrenta a força dos poderosos em nome da Justiça e da verdade: 
Há grandes prédios de concreto, gigantescos, que reduzem os personagens do filme. E sente-se bem a força do poder que estavam enfrentando. A enormidade do governo impessoal, bem como de nossa fantasia sobre ele. E contrário a isso há os pequenos cartões da Biblioteca do Congresso, que, colocados juntos, atravessarão as paredes, e farão ruir certas áreas do poder (Pakula, 1976).

Afirmamos que as passagens de Spotlight inspiradas nas redações e cotidiano dos jornalistas de Todos os homens do presidente também podem ser entendidas como uma alusão às pressões políticas presentes no jornalismo investigativo.

Com relação às representações dos jornalistas e de seu modus operandi em cenas de ação dos personagens movendo-se pela cidade (indo à biblioteca, ao fórum, à casa dos entrevistados, bares, praças, garagens, locais públicos para encontrar as fontes) -, especialmente, em Spotlight, é curioso notar que tais imagens são signos distantes do referente da rotina profissional na realidade concreta do trabalho jornalístico no século XXI. Tal como aponta Erik Neveu (2006), tem se tornado cada vez mais evidente a figura do "jornalista sentado", fenômeno de um deslocamento do jornalismo da rua para as redações e para frente do terminal do computador, sobretudo mediante o aumento dos serviços de teleapuração, edição, seleção. Mais do que ir à caça de notícias fora da empresa (newsgathering), o jornalista sentado dedica-se principalmente a receber informação (via agências, assessorias de imprensa, fontes especializadas), fazer uma triagem, decidindo o que será aproveitado, e transformá-la em material publicável pelo veículo em que trabalha.

Com efeito, o dinamismo de um profissional que vai às ruas e se movimenta por diferentes locais, encontrando-se com outras pessoas, confrontando-se com outros sujeitos sociais, é mais útil a uma narrativa cinematográfica que se pretende envolvente do que um profissional que apenas digita textos ou fica ao telefone. O ofício da investigação é mais bem ilustrado por ações mais enfáticas. Assim, outras características de valorização da imagem do jornalista investigativo vão se organizando tanto em Todos os homens do presidente como em Spotlight.

Os dois filmes também são coincidentes no reforço da imagem do jornalista como profissional 100\% envolvido com o trabalho, que não tem hora para parar. Em ambos os filmes, o conjunto de cenas ilustra que o trabalho do jornalismo investigativo significa uma dedicação praticamente exclusiva na vida dos personagens. Tarefas de apuração, de contato com as fontes e de redação dos textos são reiteradamente mostradas em cenas que se passam tarde da 
noite. Em Todos os homens do presidente, o repórter Woodward é acordado pelo chefe logo no início do filme para receber a pauta sobre a invasão ao edifício Watergate. Em Spotlight, o repórter Michael Rezendes trabalha de casa, vai à redação em seu dia de folga, paga com seu próprio dinheiro as fotocópias dos documentos que está investigando, enfim, é construído como se estivesse completamente entregue ao seu ofício. Verifica-se um reforço de uma dada imagem de trabalhadores extremamente dedicados, os quais, conforme salienta Isabel Travancas (1990), vivenciam sua profissão como uma vocação. A autora, em sua pesquisa etnográfica sobre jornalistas brasileiros na década de 1980, aponta que os profissionais enfatizam certo sentido missionário ou vocacional, como o dos médicos ou dos religiosos, que estendem para toda sua vida - e não apenas para o momento de exercício dentro da empresa - a sua função laboral.

Além de dedicado, o jornalista investigativo é representado como alguém destemido, corajoso e que chega a pôr sua vida em risco, podendo sofrer ameaças pelo trabalho que realiza. Nos dois filmes, um dos jornalistas interage com uma fonte sem rosto, o informante misterioso (no primeiro filme, o "Garganta Profunda", no segundo, Richard Sipe, o "especialista" no assunto ${ }^{3}$ ), e há cenas propositalmente pensadas para acirrar o ar de suspense. Isso é mais um paralelismo estético e narrativo nas duas obras. É particularmente interessante o modo como os filmes constroem esse sentido, porque, tanto em Todos os homens como em Spotlight, o plano sequência procura criar expectativas no público, mas ao final, nada de mal efetivamente acontece aos jornalistas.

Sobre a garagem deserta onde Woodward encontrava o "Garganta Profunda" altas horas da madrugada, Redford conta: "Sabia que tinha que fazer da garagem um vilão. Tinha que fazê-la virar uma caverna que dava medo de entrar e onde tudo podia acontecer. Tinha que ter a impressão de que alguma coisa podia pular das sombras. Tinha que ser quieta para que pudesse ouvir gotas pingando dos canos, e fica cada vez mais quieta, quando de repente um carro canta pneu e você pula de medo na cadeira". No making-of lançado na ocasião, o jornalista Bob Woodward (1976) justifica que, de fato, sentia calafrios nos encontros soturnos, e temia ser vítima de algum ataque: "Tínhamos medo, pelas nossas vidas, não sei se por pura paranoia ou não. A garagem subterrânea era aterrorizante".

3 Garganta Profunda foi o apelido dado a um informante do alto escalão do governo que passava informações a Woodward e Bernstein, cuja identidade secreta só veio a ser revelada em 2005. Richard Sipe é um ex-sacerdote da Igreja Católica, autor de livro sobre escândalos sexuais na instituição, que foi entrevistado pelos jornalistas da equipe Spotlight. No filme, ele não aparece, mas é mencionado pelos personagens, além de ter sido representado em duas cenas apenas como uma voz ao telefone. 
Podemos dizer que a narrativa ficcional heroica da atividade jornalística em investigação de casos reais, característica que une Spotlighte Todos os homens do presidente, apoia-se em elementos do senso comum fortemente presentes nas redações de jornais e disseminadas entre seus leitores. As cenas de ação, com traços de suspense, ainda que não contenham elementos que efetivamente tenham posto a vida dos jornalistas em risco, evocam a ideia de heroísmo. É um sentido implícito, mas que se deixa entrever na argumentação proposta. Os significados implícitos são recuperados pelos receptores quase sempre com base no "senso comum" (definido por aquilo que nos aparece como "dado", "natural" ou "óbvio") compartilhado socialmente pelos participantes do evento comunicacional, num processo de interdiscursividade. Fairclough (2001, p. 55) reconhece a implicitação como "uma propriedade marcante dos textos" e "de importância social considerável", uma vez que todas as formas de sociabilidade e solidariedade dependem de significados que são compartilhados e podem ser "tomados como dados".

Lopes (2007) salienta que muito do que se entende por jornalismo investigativo repousa sobre a ideia de que o jornalista presta um serviço de vigia à sociedade. $\mathrm{O}$ dever ou a missão desse profissional seria funcionar como uma sentinela, atento aos deslizes dos poderosos e denunciando-os à sociedade. Conforme Bucci (2000, p. 18), atualmente, "falar em jornalismo é falar em vigilância do poder e, ao mesmo tempo, em prestação de informações relevantes para o público, segundo os direitos e necessidades do público (não do governo)". Demonstra-se, ainda, que parte das imagens sobre a profissão deriva dos momentos de memória e autorreferenciação, que evocam tais sentidos para a identidade jornalística. Um desses é justamente o caso Watergate, envolvendo os repórteres Carl Bernstein e Bob Woodward. O trabalho investigativo deles acabou se tornando referência não só para os jornalistas americanos, mas também ocupou a memória dos brasileiros. Segundo o jornalista Luiz Nassif, na década de 1990, quando a imprensa no Brasil tratava das denúncias envolvendo o ex-presidente Fernando Collor "[...] os ecos de Watergate estavam vivos na cabeça de cada jovem jornalista brasileiro [...]"'(Nassif, 2003, p. 17). O pesquisador Marcio Castilho avalia que esse traço identitário que põe em destaque a marca da postura investigativa foi associado à identidade jornalística, no Brasil, no período final da ditadura militar. A valorização de uma identidade "investigativa" no contexto da abertura do diálogo político tem forte carga simbólica para o campo jornalístico. Ao reivindicar para si o papel de investigador, o repórter reforça, em última instância, o seu papel social (Castilho, 2010).

É justamente a relevância do papel social do jornalista investigativo que os filmes analisados procuraram ressaltar. A conclusão de ambos aponta 
para uma associação direta entre o trabalho jornalístico e a queda daqueles a quem investigaram: no primeiro caso, personagens políticos do alto escalão do governo americano, incluindo o próprio presidente dos EUA, e no segundo, o cardeal Bernard Law, clérigo superior responsável pela administração da Igreja na região de Boston, foco da cobertura jornalística do Boston Globe. Mais uma vez é possível observar o dialogismo do filme de 2015 em relação ao de 1976. Há uma preparação da emoção antes do desfecho dos filmes por meio de tensões entre jornalistas e chefia, sobretudo pela cobrança de confirmação de certas informações por uma fonte relevante e confiável. Esses conflitos perpassam praticamente toda a narrativa. E quando se aproxima o final do filme, acirrase a preocupação com o fator tempo, com fatos que apontam para a urgência da publicação das matérias. Quando as chefias aprovam a publicação, os dois filmes, cada um a seu modo, exibem planos-sequência relacionados com o passo-a-passo da rotina para que o impresso chegue às bancas e às mãos dos leitores. É especialmente curioso notar como um filme de 2015, em plena era da comunicação à distância, explora com detalhes as imagens de jornais sendo produzidos na gráfica e sendo distribuídos por caminhões.

Por fim, os filmes encerram com cenas que sugerem ao espectador que a renúncia dos poderosos denunciados foi uma consequência do trabalho jornalístico. No mais antigo, as cenas finais mostram frases digitadas em máquinas de escrever informando sobre o destino de Nixon e de outros homens do presidente. No mais recente, letreiros em fundo preto informam o destino do cardeal Law, além de listarem outras cidades em que houve confirmação de casos de pedofilia envolvendo padres. Chancelam a ideia de que a ação de jornalistas é por si só capaz de derrubar presidentes (e arcebispos), visão "grosseiramente exagerada" na visão de Lins da Silva (1991) citado por (Oliveira, 2005, p. 39).

\section{O cinema e o jornalismo como construções contextualizadas}

A reflexão proposta a seguir pode ser estendida tanto para o caráter discursivo do jornalismo e da produção noticiosa quanto para o discurso cinematográfico. As representações construídas pelo jornalismo ou pelo cinema jamais podem ser tomadas como relato translúcido dos fatos, embora ambos, cada qual a seu modo, tendam a fazer alegações desse tipo. Entrevistas com diretores e produtores dos filmes sinalizam essas tendências, além de outros direcionamentos dados à produção cinematográfica que também serão comentados à frente.

Contribuições teóricas de analistas do discurso chamam a atenção para alguns aspectos a serem considerados. Duarte e Pinto (2005) lembram que a 
interpretação de qualquer texto para a análise de discursos nunca se prende exclusivamente ao enunciado formulado, pois se faz a partir de informações colhidas em três dimensões: no contexto situacional (o ambiente físico e institucional em que o texto é produzido, circula e é consumido), no contexto (outros textos situados fisicamente ao redor do texto ou de qualquer fragmento dele), e nos contextos das ordens de discursos ou interdiscursos (outros textos produzidos no mesmo quadro institucional ou relativos à mesma área de conhecimento e afins, que são mobilizados intertextualmente na interpretação).

Para efeitos de ideologia e poder, um princípio metodológico fundamental da análise textualmente orientada dos discursos diz respeito ao gênero do discurso, que possui papel central ao relacionar "falas" a "lugares culturais" (Maingueneau, 1998, p. 73). As instâncias de enunciação são formuladas em termos de lugares para enfatizar a preeminência e a preexistência da topografia social sobre os falantes que nela venham a se inscrever (Maingueneau, 1997). Devido à determinação sócio-histórica dos dispositivos de enunciação, cada texto pertence a um gênero de discursos ou a uma espécie de discurso. Os gêneros pressupõem dispositivos de enunciação, em que se explicitam os diferentes "lugares de fala", maneiras de construir a representação de uma determinada prática social ou área do conhecimento propostas pelos sujeitos que aparecem nos textos e que são assumidas ou não pelos participantes do evento comunicativo (Pinto, 1999, p. 29).

Comparando as duas obras, cabe pontuar que o filme Todos os homens foi baseado num livro homônimo, dos próprios jornalistas, enquanto isso não ocorreu em Spotlight, cujo roteiro foi escrito 13 anos depois das reportagens do Boston Globe, por outras pessoas. Porém, em ambos os casos foram realizadosnos moldes das obras fílmicas que já se intencionava produzir. Para ilustrar a questão da intencionalidade e da não-gratuidade do formato narrativo, basta imaginar que, das inúmeras maneiras possíveis de se representar o escândalo da Igreja de Boston com a questão da pedofilia, os responsáveis pelo filme Spotlight poderiam contar diferentes histórias, por exemplo, evidenciando a perspectiva das vítimas; ou então, a partir da versão dos sacerdotes não-coniventes com a situação que, entretanto, não conseguiram ser ouvidos; enfim, com outros personagens que até são mencionados no filme, mas que não serviram ao eixo central da história ou foram propositalmente silenciados. Vale lembrar que se trata da indústria de Hollywood (e não de cinema independente e/ou alternativo), com vistas a alcançar ampla distribuição, bilheteria expressiva e também reconhecimento público pelas instâncias de consagração do cinema, como a premiação do Oscar. A opção discursiva de Spotlight foi deixar em evidência o "lugar de fala" do jornalismo, em claro dialogismo com Todos os homens do presidente. 
NocasodofilmesobreWatergate, informaçõesrelacionadascomocontexto de produção tanto do livro quanto do filme (o primeiro lançado dois anos antes do segundo) demonstram que a lógica cinematográfica também teve influência na elaboração do próprio livro. Mais do que isso: os jornalistas foram induzidos pelo ator e produtor Robert Redford a se tornarem protagonistas do livro que estavam escrevendo sobre o Caso Watergate, como afirmam em documentário por ocasião dos 30 anos do filme. Redford diz que foram os jornalistas por trás da história que o intrigaram durante a cobertura - passaram-se mais de dois anos entre a invasão à sede do partido Democrata e a renúncia de Nixon:

Eu prestei atenção ao trabalho que estes caras fizeram, e outros não. Quem são estes dois caras? Adoro a ideia de que estavam trabalhando duro, começando no nível mais baixo da carreira, e o trabalho deles iria derrubar o maior poder da nação. Liguei para o Woodward em Washington e disse "quero falar com você, tive uma ideia" (Redford, 2006).

A proposta de Robert Redford era tornar visíveis - e mesmo heróis aqueles dois anônimos, usando seu prestígio para negociar a história com o estúdio Warner. Em Telling the true about lies, ele se lembra de ter dito aos repórteres do Post:"Meu interesse são vocês (2006). Na história pessoal, em como vocês trabalharam. Quero mostrar que há uma história por trás da história". E os convenceu não apenas a vender os direitos do livro que estavam escrevendo, como também a redirecionar a história para si mesmos. Na época, o livro que Woodward e Bernstein tinham em mente não os incluía como personagens. lam escrever uma narrativa padrão sobre o governo de Nixon. "O livro que começamos a escrever não era sobre nós. Era sobre Watergate! Woodward me procurou um dia e disse que Redford tinha ligado para ele: Ele acha que a história na verdade somos nós", lembra Bernstein no documentário. No making-of de Todos os homens do presidente lançado em 1976, Bernstein destaca que ficou impressionado com Redford, por querer fazer "um filme sério sobre a indústria jornalística" e comprar os direitos do livro antes mesmo de fechar com a Warner.

Os produtores de Spotlight, ByleFaust e Nicole Rocklin, também salientaram que a opção narrativa deles incluía o protagonismo dos jornalistas. Segundo eles, em entrevista ${ }^{4}$ concedida em outubro de 2015 ao Boston Globe,

4 Reportagem do Boston Globe de 30/10/2015 informa que os produtores Nicole Rockling e BlyeFaust receberam a proposta de um filme sobre os escândalos sexuais envolvendo a Igreja Católica, sobretudo tentando responder "por que demorou uma sucessão de três cardeais e muitos bispos em 34 anos para tirar as crianças do alcance de Geoghan [padre incriminado por pedofilia]" (Goldstein, 2015). Decidiram fazer não um filme sobre o escândalo propriamente dito, mas sobre os jornalistas que o investigaram; e, em 2009, começaram a verificar a questão dos direitos para exibição de pessoas reais no cinema. 
na ocasião da estreia no cinema, fazer um filme nesses moldes e não sobre os escândalos propriamente ditos foi uma opção quase natural: "foi imediato, foi óbvio desde o início" (Faust, in Goldstein, 2015).

Queremos enfatizar, porém, que o protagonismo dos jornalistas nos filmes não pode ser considerado nem natural, nem óbvio, nem gratuito. 0 autor empírico de um texto (o indivíduo que o produziu fisicamente) não se confunde com o sujeito do enunciado ou narrador (em textos narrativos) ou emissor (denominado locutor, nos textos orais). O sujeito do enunciado é um personagem entre outros personagens que agem e falam nos textos (outros sujeitos do enunciado) e que no próprio enunciado é apresentado como seu responsável. Num filme, o emissor (diretor do filme, por exemplo) assume alguns significados como premissas ou suposições que embasam a sua obra, definindo-se como sujeito da enunciação. Na tensão entre emissor e receptorintérprete, os enunciados proferidos podem atribuir outros implícitos ao receptor, que, ao aderir a eles, torna-se um co-enunciador desses enunciados (na produção de um intertexto consensual ou senso comum). Os enunciados podem ser proferidos por terceiros (personagens do filme, por exemplo), que passam a ser reconhecidos como sujeitos do enunciado. A autoridade e a legitimidade conferidas à identidade jornalística (Lopes, 2013) são certamente fatores decisivos para que os diretores e produtores dos filmes tenham feito a escolha que fizeram pelo pressuposto de que, com suas denúncias jornalistas, derrubaram poderosos. Nessa narrativa unitária e coerente, porém, algumas fissuras aparecem e formam "vozes dissonantes", que deixam marcas formais de conflitos não representados.

Num primeiro nível de análise, cabe ao investigador percorrer os aspectos formais do texto, que exemplificamos aqui com sequências narrativas de Spotlight: a) a equipe Spotlight é cobrada por não investigar as denúncias de pedofilia pelo novo editor executivo da redação, que assume a postura de abrir uma disputa judicial para obter acesso a documentos sigilosos com base na Primeira Emenda; b) no período de apuração, repórteres são reiteradamente informados que as denúncias contra pelo menos 20 padres haviam sido formalizadas e ignoradas pelo jornal; c) caracterização do editorchefe do Spotlight como jornalista talentoso e dedicado; d) caracterização dele também como "cerebral", estratégico e tecnicamente superior, num conflito com o repórter Michael Rezendes para adiar a publicação da reportagem Rezendes tem uma reação emocional e, movido pela indignação, quer publicar de imediato a matéria que revelaria a proteção do cardeal Law a um padre pedófilo: o editor mostra frieza, pois quer denunciar o "sistema", mostrando que não se trata de um caso isolado (o que poderia poupar o cardeal, capaz de 
alegar que houve um "erro isolado"); e) recuperação de uma notícia do jornal em que se lê a manchete sobre a denúncia contra 20 padres; e) fala do editor do Spotlight, em que ele atribui à própria inexperiência a "falha técnica" de não haver aprofundamento das denúncias ("eu estava começando como editor de Cidade", diz o editor na tradução em português); f) reação geral da equipe Spotlight e do editor executivo da redação do jornal, de anuência à justificativa.

O conjunto desses núcleos narrativos revelam o processo de implicitação discursiva pelo qual o enunciador e os sujeitos do enunciado buscam conferir um aspecto unitário à narrativa, ao mesmo tempo em que promovem o esvaziamento do caráter público e político das decisões tomadas no processo de seleção dos acontecimentos e produção da notícia. Esse caráter negociado da produção da notícia tem sido debatido por teóricos associados ao newsmaking, perspectiva teórica em que sobressaem estudos sobre a cultura profissional e a rotina organizacional do trabalho jornalístico como limites para estabelecer a noticiabilidade de um acontecimento e sua consequente marcação como evento de relevância pública (Wolf, 1992).

Os"valores-notícia"são esses critérios e operações padronizados usados no dia a dia dos jornalistas para seleção rápida e rotineira dos fatos e gerenciamento das notícias. Eles estão presentes em todo o processo de construção noticioso e são dinâmicos (podem mudar no tempo ou de acordo com a redação). Esse caráter negociado, entretanto, nada tem a ver com manipulações grosseiras, denunciadas em crenças conspiratórias presentes em determinadas visões do senso comum sobre a imprensa. Trata-se de um caráter constitutivo de qualquer notícia, honesta ou desonestamente construída.

A perspectiva do newsmaking destaca as notícias como resultado de estratégias discursivas, e não como informações as serem anotadas e relatadas, o que ressalta o poder do jornalismo na marcação dos acontecimentos que merecem aparecer como importantes ou interessantes na esfera pública. A notícia é um processo de interação social que implica uma aguda negociação e construção de sentidos. A imprensa não é simplesmente um "holofote" a jogar luz nos fatos ocultos pelos poderosos, mas também possui participação central na construção da realidade e das identidades sociais. Como um conta-gotas mental, as notícias desempenham um papel transformador em longo prazo, pela exposição cotidiana em que produz um efeito cumulativo, buscando influenciar o público receptor na forma como estrutura as representações sobre a realidade social, suas opiniões e crenças (Wolf, 1992).

O conflito não representado deve estender as negociações de sentido ao próprio poder das fontes. Em Todos os homens, há referências sobre o poder dos partidos políticos e de figuras políticas em particular; e mostra-se a pressão 
sofrida por certas fontes para que não conversem com a imprensa. Spotlight faz alusões ao poder da Igreja na cidade de Boston e às dificuldades de investigar o abuso de menores pelo padre John Geoghan, e a negligência da Arquidiocese de Boston. Existem várias angulações possíveis no processo de produção da notícia, que ressaltam seu caráter de "construção discursiva da realidade social". O jornalista é regido pela lógica da objetividade e da imparcialidade predominante no fazer jornalístico, mas, na prática, é afetado por fatores que o levam a interagir socialmente e a realizar negociações durante o processo de produção da notícia.

Molotch e Lester citado por (Traquina, 1993, p. 34) mostram que o acontecimento público é precedido por uma série de agências (indivíduos e grupos) que ajudam a construí-lo (muitas vezes, no limite de rotinas organizacionais). A primeira dessas agências são os "news promoters", as fontes diretas dos jornalistas (os "newsassemblers"). Quando esses promotores de notícia são fontes institucionais, Hall (1997) os classifica como "definidores primários" de pautas e ângulos para a imprensa (definidor secundário). Para Hall, as pressões internas da rotina produtiva contra o tempo e as exigências de imparcialidade e objetividade levam a imprensa a privilegiar essas fontes que detêm posição de credibilidade institucional.

Não há aqui espaço para aprofundar a complexa relação dos jornalistas com as fontes institucionalizadas, como são os partidos políticos, a lgreja etc. Mas o resumo acima ao menos nos permite avaliar que, em alguns momentos, essas são algumas das instituições que procuram a imprensa para tornar legítimas suas pretensões e obter apoio público. Mas também é sempre importante considerar as diferenças de proporção de poder entre as variadas instituições que estabelecem relações com a imprensa. Esse, entretanto, é um tema que merece um estudo específico.

\section{Palavras finais}

Ao longo deste texto, foram salientadas muitas similaridades e paralelismo entre as obras fílmicas. Porém, para finalizar, é interessante destacar que a intencionalidade na produção de ambos constitui uma diferença pertinente entre eles. Como se viu, Todos os homens do presidente foi lançado em 1976, mas começou a ser produzido em 1974, quando da renúncia de Nixon ao cargo de presidente dos EUA. Boa parte da narrativa fílmica se baseou nos relatos e na percepção dos próprios jornalistas envolvidos. É interessante considerar que esse dado contextual acerca da produção cinematográfica é bastante significativo: a publicização de uma narrativa fílmica bastante próxima ao calor dos acontecimentos e a vinculação estreita do roteiro do filme com as vozes 
dos próprios jornalistas aponta para uma contribuição recíproca da dimensão discursiva como prática social. Não se esquecendo da influência do produtor Robert Redford na própria concepção do livro que os jornalistas Bernstein e Woodward escreveram, observa-se que em Todos os homens do presidente há grande consonância entre os discursos de jornalistas e da equipe que produziu o filme, efetivando uma sintonia que ajuda a reforçar as imagens de jornalismo investigativo que o próprio universo jornalístico procurou sustentar socialmente.

As reportagens jornalísticas que resultaram do trabalho de investigação da equipe Spotlight começaram a vir à tona em janeiro de 2002, tendo sido publicadas regularmente pelo jornal naquele ano, porém, o filme só foi lançado em 2015, ou seja: 13 anos depois do fato. Em entrevista ao Boston Globe (30/10/2015), os próprios produtores informaram que os primeiros preparativos para a criação de um filme referente à questão do escândalo sexual envolvendo padres americanos acusados de pedofilia iniciaram em 2009. Um dos trabalhos necessários à produção foi a de levantar os direitos de exibição da vida dos envolvidos na história. Certamente, conseguir tais autorizações com os padres acusados ou com as vítimas seria inegavelmente mais difícil - quiçá impossível - do que com os jornalistas que fizeram investigações e foram, eles próprios, responsáveis pelas informações que publicaram à época.

Além disso, o jornalismo é uma profissão envolta de estereótipos e clichês dos quais o cinema faz muito proveito. Trabalhar a imagem desses profissionais como mocinhos contra vilões é uma estratégia bastante eficiente de mobilização do público, pois já aproveita sentidos cristalizados, sobretudo nos EUA, sobre as qualidades associadas à identidade jornalística. Esse universo também fornece elementos para narrativas que exploram o suspense, a vinculação emocional a alguém que precisa vencer desafios para cumprir sua missão. Neste sentido, a figura do jornalista é bastante rica para a indústria cinematográfica.

Todos os homens do presidente não pode ser considerado a apresentação inaugural, à sociedade americana, do trabalho da imprensa em seu tempo, já alimentado pela ficção, especialmente pelo repórter herói Clark Kent, criado por Jerry Siegel nos anos 1930. Mas, até mesmo por caráter documental e tributário ao trabalho do jornalista, proporcionou um fascínio pela profissão até então jamais visto, nos Estados Unidos e no mundo, inclusive no Brasil. Spotlight, 40 anos depois, num momento de crise de modelos, de descrédito e questionamento sobre o papel da imprensa na sociedade, foi capaz de reacender este fascínio pelo jornalismo.

Em suma, a observação dos elementos textuais nas duas obras aponta para representações reiteradas sobre um suposto heroísmo dos jornalistas e a sugestão de que o jornalismo investigativo tem o poder de derrubar poderosos 
desonestos. Esse tipo de narrativa, entretanto, busca evitar a simbolização do caráter negociado e construtivo das notícias, num processo complexo que buscamosapontareexplicitar, mesmoquesuperficialmente.Porém, defendemos que essa dimensão não-representada reaparece em fissuras das narrativas, por meio de implicitações discursivas (pressupostos e subentendidos). Essas fissuras são enunciações que buscam esvaziar o caráter político (público) de conflitos no gerenciamento da notícia pelos jornalistas e o exercício de poder nessa construção da notícia e da realidade social. Trata-se de impor ao público o compartilhamento da notícia como um "espelho da realidade", isto é, mera transmissão de informação ou relato neutro dos fatos.

As teorias críticas do discurso não reconhecem uma fronteira rígida entre os níveis argumentativos e descritivos da linguagem. Isto é, a descrição da realidade nunca é neutra, pois toda descriçãoé um momento de algum esquema de argumentação e classificação do mundo. A aparente neutralidade da narrativa (descritiva) noticiosa decorre dos elementos "naturalizados" (senso comum), que empregamos de forma automática, o que pressupõe a invisibilidade dos mecanismos discursivos que regulam a eficiência da argumentação. Os fatos não falam "por si mesmos", mas são levados a falar por uma rede de mecanismos discursivos presentes num dado contexto. Daí a importância de questionar "como" (de que lugar cultural) alguém percebe (interpreta) os argumentos.

Bakhtin descreveu a consciência como uma internalização de palavras, um tipo de "discurso interior" (Stam, 1992), mas este não é um movimento pacífico, devido à multiplicidade de vozes no ambiente social, à polifonia. É um processo pensado como uma arena de luta pelo sentido, um processo dinâmico de significação, o dialogismo. Pensar o nível da interação é, portanto, perceber o discurso como território compartilhado, levar em conta os efeitos de sentido em recepção, pensar o lugar atribuído ao destinatário como determinante do ideológico de um texto. Por meio dos subentendidos, as representações nos filmes se apoiam em duas crenças básicas e estereotipadas de seus espectadores: a credibilidade do jornalista em falar dos fatos e o seu dever de neutralidade (reverberando, em muitas cenas, a "teoria do espelho"). Escolhendo-os como sujeitos do enunciado de boa parte das narrativas, os filmes apoiam-se nesses sentidos associados aos jornalistas. Com visto, não é uma escolha gratuita. Demonstramos que, ao mobilizar tais representações, as obras fílmicas também postulam para si próprias um lugar de fala; buscam não só credibilidade e reconhecimento, mas também prestígio, fama, audiência, além de, elas próprias, apresentarem-se como discursos "neutros" sobre os fatos que abordam. 


\section{Referências}

BAKHTIN, Mikhail. Marxismo e Filosofia da Linguagem. São Paulo: Hucitec, 1986.

Estética da comunicação verbal. São Paulo, Martins Fontes, 1992.

BECKER, Howard. Métodos de pesquisa em ciências sociais. São Paulo: Hucitec, 1994.

BERGER, Christa (Org.). Jornalismo no cinema. Porto Alegre: Editora da UFRGS, 2002.

BERNSTEIN, Carl. Depoimento [1976] em Pressure and the press: The making of all the president's men. Produção: Andrew J. Kuehn, Dave Gilbert e Bill Cox. Warner Bros./Kaleidoscope Films, EUA, 1976. Disponível em: www.youtube.com/ watch?v= uw1Rz9Y69s4. Acesso em: 3 mar. 2017.

.Depoimento [2006] em All the president's men - Telling the true about lies. Documentário extra da edição especial de 30 anos do filme. Texto, produção e direção: Gary Leva. Leva FilmWorks, Inc. EUA, 2006. Disponível em: www. levafilmworks. com/all-the-presidents-men. Acesso em: 26 fev. 2017.

CASTILHO, Marcio. Um patrimônio dos próprios jornalistas: o Prêmio Esso, a identidade profissional e as relações entre imprensa e Estado (1964-1978). 2010. Tese (Doutorado em Comunicação) - Escola de Comunicação da UFRJ, Rio de Janeiro, 2010.

CHARAUDEAU, Patrick; Maingueneau, Dominique. Dicionário de Análise do Discurso. São Paulo: Editora Contexto, 2006.

DUCROT, O. Le direetledit. Paris: Minuit, 1984.

FAIRCLOUGH, Norman. Discurso e mudança social. Brasília: Editora Univ. de Brasília, 2001.

HALL, Stuart. The work of representation. In: (org.) Representation: cultural representation and cultural signifying practices. London/Thousand Oaks/New Delhi: Sage/Open University, 1997.

HOFFMAN, Dustin. Depoimento [2006] All the president's men - Telling the true about lies. Documentário extra da edição especial de 30 anos do filme. Texto, produção e direção de Gary Leva. Leva FilmWorks, Inc. EUA, 2006. Disponível em: www.levafilmworks.com/all-the-presidents-men. Acesso em: 26 fev. 2017.

GOLDSTEIN, Meredith. “How the Spotlight movie was made". Boston Globe, 30/10/2015.

Disponível em: http://www.bostonglobe.com/lifestyle/names/2015/10/30/ how-spotlight-movie-got-made/wXVXUiYPkoF3hEP9K4dydP/story.html. Acesso em:14 nov. 2016.

KERBRAT-ORECCHIONI, C. L'implicite. Paris: Armand Colin, 1986. 
LOPES, Fernanda Lima. Ser jornalista no Brasil: identidade profissional e formação acadêmica. São Paulo: Paulus, 2013.

Autorreferenciação e construção da identidade jornalística. 2007. Dissertação (Mestrado em Comunicação Social) - Escola de Comunicação, UFRJ, Rio de Janeiro, 2007.

MAINGUENEAU, Dominique. Novas Tendências em Análise do Discurso. Campinas: Editora Pontes, 1997.

MAINGUENEAU, Dominique. Termos-chave da Análise do Discurso. Belo Horizonte: Editora UFMG, 1998.

MOLOTCH, Harvey; LESTER, Marilyn. As notícias como procedimento intencional: acerca do uso estratégico de acontecimentos de rotina, acidentes e escândalo. In: TRAQUINA, Nelson (org.). Jornalismo: questões, teorias, estórias. Lisboa: Veja, 1993.

TRAQUINA, Nelson (Org.). Jornalismo: questões, teorias e estórias. Lisboa: Vega, 1993.

NASSIF, Luis. O jornalismo dos anos 90. São Paulo: Futura, 2003.

OLIVEIRA, Michele Roxo de. Profissão jornalista: um estudo sobre representações sociais,identidade profissional e as condições sociais de produção da notícia. 2005. Dissertação (Mestrado em Comunicação) - FAAC, Universidade Estadual Paulista,Bauru, 2005.

O'REILLY, Tim. O que é Web 2.0: Padrões de design e modelos de negócios para a nova geração de software. O’Reilly Media, Inc, 30/09/2005.Disponível em: https:// edisciplinas.usp.br/pluginfile.php/114173/mod resource/content/1/o-que-eweb-20 Tim\%200\%C2\%B4Reilly.pdf. Acesso em: 16 mar. 2017.

PAKULA, Allan J. Depoimento [1976] em Pressure and the press: The making of all the president's men. Produção: Andrew J. Kuehn, Dave Gilbert e Bill Cox. Warner Bros./KaleidoscopeFilms, EUA, 1976. Disponível em: www.youtube.com/ watch?v= uw1Rz9Y69s4. Acesso em: 3 mar. 2017.

PAVLIK, John. Journalism and new media. Nova York: Columbia University Press, 2001.

PINTO, Milton José. Comunicação e discurso. São Paulo: Hackers, 2002.

PINTO, Milton José; DUARTE, Maurício da Silva. Discurso, implícitos e Ideologia: As ONGs e a visão arcaica da relação entre público e privado. In: RIBEIRO, Ana Paula Goulart; PINTO, Milton José (Org.). Discursos: Coleção de Estudos da Linguagem Como Prática Social. Rio de Janeiro: Editora Ilustração, 2005, v. único, p. 31-46. 
REDFORD, Robert. Depoimento [2006] All the president's men - Telling the true about lies. Documentário extra da edição especial de 30 anos do filme. Texto, produção e direção de Gary Leva. Leva Film Works, Inc. EUA, 2006. Disponível em: www.levafilmworks. com/all-the-presidents-men. Acesso em: 26 fev. 2017.

SANTOS, Marcelle Khouri. Um olhar sobre jornalismo: análise da representação do jornalismo no cinema hollywoodiano, de 1930 a 2000. 2009. Dissertação (Mestrado em Jornalismo) - Universidade Federal de Santa Catarina, Florianópolis, 2009.

STAM, Robert. Bakhtin: da teoria literária à cultura de massa. São Paulo, Ática, 1992.

TRAQUINA, Nelson. A notícia. In: TRAQUINA, Nelson (Org.). Jornalismo: questões, teorias e estórias. Lisboa: Vega, 1993.

TRAVANCAS, Isabel Siqueira. O mundo dos jornalistas. São Paulo: Summus, 1992.

WOLF, Mauro. Teorias da comunicação. Lisboa: Presença, 1992.

WOODWARD, Bob. Depoimento [1976] em Pressure and the press: The making of all the president's men. Produção: Andrew J. Kuehn, Dave Gilbert e Bill Cox. Warner Bros/KaleidoscopeFilms, EUA, 1976. Disponível em: www.youtube.com/ watch?v= uw1Rz9Y69s4. Acesso em: 3 mar. 2017.

Recebido em: 19/3/2017

Aceito em: 31/3/2017

Endereço dos autores:

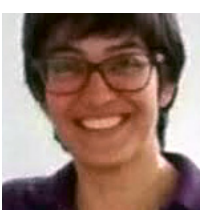

Fernanda Lima Lopes <ferdynanda@yahoo.com $>$

Escola de Comunicação da Universidade Federal do Rio de Janeiro (UFRJ)

Avenida Pasteur, 250 - Praia Vermelha

22290-240 - Rio de Janeiro (RJ) - Brasil

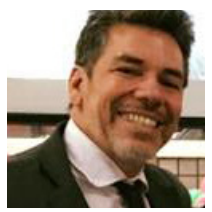

Maurício da Silva Duarte <dmausage@gmail.com>

Universidade Salgado de Oliveira

Bloco A, R. Mal. Deodoro, 217 - Centro

24030-060 - Niterói (RJ) - Brasil

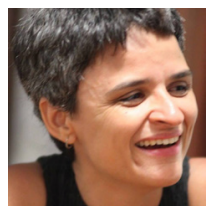

Itala Maduell Vieira <italamad@gmail.com>

Pontifícia Universidade Católica do Rio de Janeiro (PUC-Rio)

Rua Marquês de São Vicente, 225 - Gávea

22430-060 - Rio de Janeiro (RJ) - Brasil 